OPEN ACCESS

Edited by:

Jian Yin,

Jiangnan University, China

Reviewed by:

Bruno Linclau,

University of Southampton,

United Kingdom

Xiaodong Shi,

University of South Florida,

United States

*Correspondence:

De-Cai Xiong

decai@bjmu.edu.cn

Xin-Shan Ye

xinshan@bjmu.edu.cn

${ }^{\text {t}}$ These authors have contributed equally to this work

Specialty section: This article was submitted to

Organic Chemistry, a section of the journal

Frontiers in Chemistry

Received: 18 October 2021 Accepted: 01 December 2021 Published: 23 December 2021

Citation:

Luo Z-X, Liu M, Li T, Xiong D-C and Ye X-S (2021) Electrochemical Bromination of Glycals.

Front. Chem. 9:796690.

doi: $10.3389 /$ fchem.2021.796690

\section{Electrochemical Bromination of Glycals}

\author{
Zhao-Xiang Luo ${ }^{1 \dagger}$, Miao Liu ${ }^{1 \dagger}$, Tian $\mathrm{Li}^{1}$, De-Cai Xiong ${ }^{1,2 *}$ and Xin-Shan $\mathrm{Ye}^{1 *}$ \\ ${ }^{1}$ State Key Laboratory of Natural and Biomimetic Drugs, School of Pharmaceutical Sciences, Peking University, Beijing, China, \\ ${ }^{2}$ State Key Laboratory of Pharmaceutical Biotechnology, School of Life Sciences, Nanjing University, Nanjing, China
}

Herein, the convenient one-step electrochemical bromination of glycals using $\mathrm{Bu}_{4} \mathrm{NBr}$ as the brominating source under metal-catalyst-free and oxidant-free reaction conditions was described. A series of 2-bromoglycals bearing different electron-withdrawing or electron-donating protective groups were successfully synthesized in moderate to excellent yields. The coupling of tri-O-benzyl-2-bromogalactal with phenylacetylene, potassium phenyltrifluoroborate, or a $6-\mathrm{OH}$ acceptor was achieved to afford 2Cbranched carbohydrates and disaccharides via Sonogashira coupling, Suzuki coupling, and Ferrier rearrangement reactions with high efficiency. The radical trapping and cyclic voltammetry experiments indicated that bromine radicals may be involved in the reaction process.

Keywords: electrochemistry, bromination, glycals, 2-bromoglycals, cross-coupling, ferrier rearrangement

\section{INTRODUCTION}

Carbohydrates mainly exist in the form of glycoconjugates, polysaccharides, oligosaccharides, and monosaccharides and play a pivotal role in a broad range of important biological processes including cell proliferation, host-pathogen interactions, cell adhesion, hormone function, and the immune response (Kiessling and Kraft, 2013; Wang et al., 2020). Chemical synthesis can afford both naturally occurring important carbohydrates and biologically active carbohydrate mimetics in sufficient quantities, providing a powerful tool to understand the biological functions of carbohydrates (Muthana et al., 2009; Panza et al., 2018; Li and Ye, 2020).

Organic electrosynthesis is of current interest as one of the most promising methods for the efficient, sustainable, and green synthesis of medicinally significant compounds (Francke and Little, 2014; Horn et al., 2016; Liang and Zeng, 2020; Meyer et al., 2020; Yuan et al., 2021). In recent years, the electrochemical synthesis of oligosaccharides has been successfully demonstrated through the activation of different types of glycosyl donors, such as thio-, seleno-, and telluro-glycosides (Nokami et al., 2015; Manmode et al., 2018; Zhang et al., 2020). In addition, our group has been involved in the electrochemical transformation of glycals to obtain significant synthetic carbohydrate compounds (Liu et al., 2020; Liu et al., 2021). Along with the use of $\mathrm{MnBr}_{2}$ as the redox mediator, the electrochemical trifluoromethylation of glycals has been realized (Liu et al., 2021). In the exploration of this reaction, we found that 2-bromoglycals could also be isolated when the equivalent of $\mathrm{Bu}_{4} \mathrm{NBr}$ was added. Inspired by this surprising result, we turned our focus to the electrochemical bromination of glycals (Scheme 1).

Over the past few decades, 2-bromoglycals have been widely employed as important synthons in combination with metal-catalyzed cross-coupling reactions to access 2C-branched carbohydrates and their analogs (Leibeling et al., 2010a; Leibeling et al., 2010b; Leibeling and Werz, 2012; Dharuman and Vankar, 2014; Martin et al., 2015). Due to the importance of 


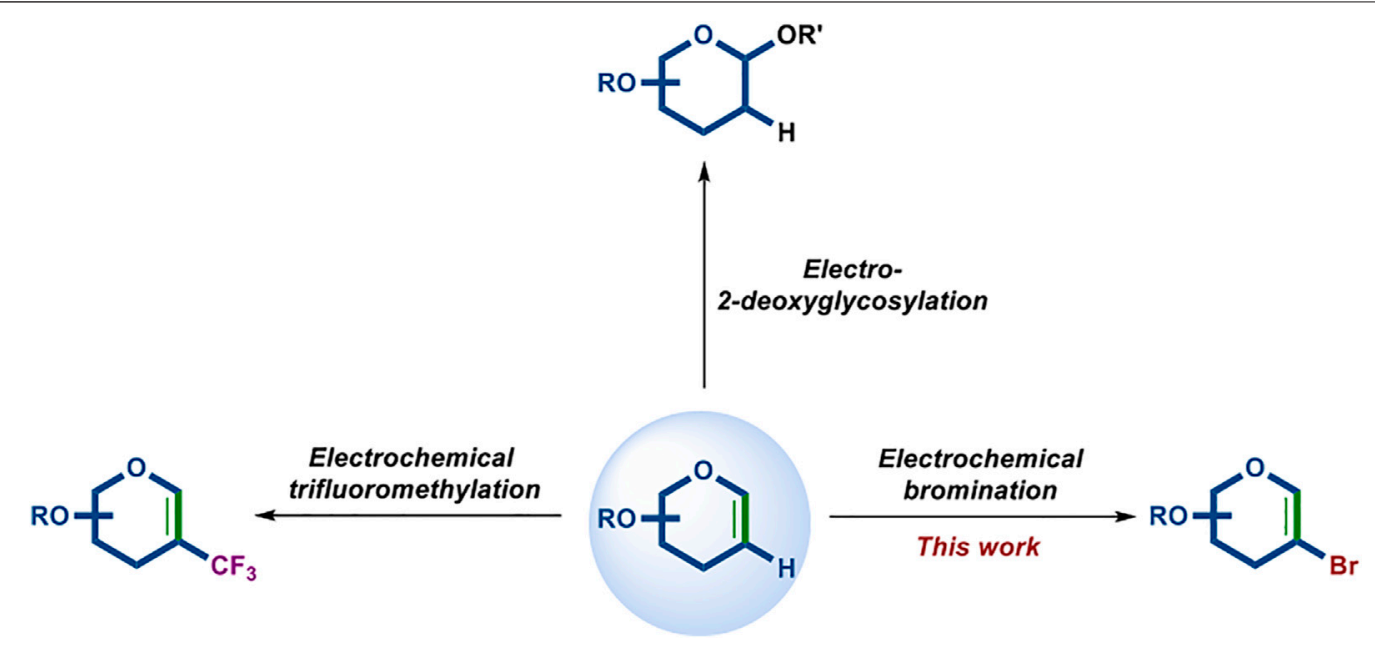

SCHEME 1 | Electrochemical transformation of glycals.

TABLE 1 | Optimization of reaction conditions ${ }^{a}$.

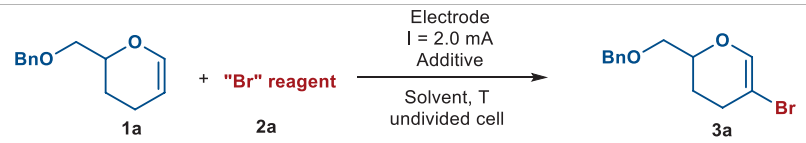

\begin{tabular}{|c|c|c|c|c|c|c|}
\hline Entry & Electrode & “Br" reagent & Additive & Solvent & $\mathbf{T}\left({ }^{\circ} \mathrm{C}\right)$ & Yield $(\%)^{b}$ \\
\hline 1 & $\mathrm{Pt}(+) / \mathrm{Pt}(-)$ & $\mathrm{KBr}$ (1.5 equiv) & - & $\mathrm{CH}_{3} \mathrm{CN}$ & $\mathrm{Rt}$ & $0(0)$ \\
\hline 2 & $\mathrm{Pt}(+) / \mathrm{Pt}(-)$ & $\mathrm{NaBr}$ (1.5 equiv) & - & $\mathrm{CH}_{3} \mathrm{CN}$ & $\mathrm{Rt}$ & $0(0)$ \\
\hline 3 & $\mathrm{Pt}(+) / \mathrm{Pt}(-)$ & $\mathrm{Bu}_{4} \mathrm{NBr}$ (1.5 equiv) & - & $\mathrm{CH}_{3} \mathrm{CN}$ & Rt & $10(0)$ \\
\hline 4 & $\mathrm{Pt}(+) / \mathrm{Pt}(-)$ & $\mathrm{Bu}_{4} \mathrm{NBr}$ (1.5 equiv) & - & $\mathrm{CH}_{3} \mathrm{CN}$ & $50^{\circ} \mathrm{C}$ & $18(14)$ \\
\hline 5 & $\mathrm{Pt}(+) / \mathrm{Pt}(-)$ & $\mathrm{Bu}_{4} \mathrm{NBr}$ (1.5 equiv) & - & $\mathrm{CH}_{3} \mathrm{CN}$ & $75^{\circ} \mathrm{C}$ & $35(10)$ \\
\hline 6 & $\mathrm{Pt}(+) / \mathrm{Pt}(-)$ & $\mathrm{Bu}_{4} \mathrm{NBr}$ (2.0 equiv) & - & $\mathrm{CH}_{3} \mathrm{CN}$ & $75^{\circ} \mathrm{C}$ & $40(13)$ \\
\hline 7 & $\mathrm{Pt}(+) / \mathrm{Pt}(-)$ & $\mathrm{Bu}_{4} \mathrm{NBr}$ (2.0 equiv) & $\mathrm{K}_{2} \mathrm{CO}_{3}$ (1.2 equiv) & $\mathrm{CH}_{3} \mathrm{CN}$ & $75^{\circ} \mathrm{C}$ & $43(4)$ \\
\hline 8 & $\mathrm{Pt}(+) / \mathrm{Pt}(-)$ & $\mathrm{Bu}_{4} \mathrm{NBr}$ (2.0 equiv) & $\mathrm{Na}_{2} \mathrm{CO}_{3}$ (1.2 equiv) & $\mathrm{CH}_{3} \mathrm{CN}$ & $75^{\circ} \mathrm{C}$ & $54(6)$ \\
\hline 9 & $\mathrm{Pt}(+) / \mathrm{Pt}(-)$ & $\mathrm{Bu}_{4} \mathrm{NBr}$ (2.0 equiv) & $\mathrm{NaSO}_{2} \mathrm{CF}_{3}$ (1.2 equiv) & $\mathrm{CH}_{3} \mathrm{CN}$ & $75^{\circ} \mathrm{C}$ & $67(0)$ \\
\hline 10 & $\mathrm{Pt}(+) / \mathrm{Pt}(-)$ & $\mathrm{Bu}_{4} \mathrm{NBr}$ (2.0 equiv) & $\mathrm{NaSO}_{2} \mathrm{CF}_{3}$ (2.0 equiv) & $\mathrm{CH}_{3} \mathrm{CN}$ & $75^{\circ} \mathrm{C}$ & $82(0)$ \\
\hline 11 & $\mathrm{Pt}(+) / \mathrm{Pt}(-)$ & $\mathrm{Bu}_{4} \mathrm{NBr}$ (2.0 equiv) & $\mathrm{NaSO}_{2} \mathrm{CF}_{3}$ (2.0 equiv) & $\mathrm{CH}_{3} \mathrm{CN} / \mathrm{H}_{2} \mathrm{O}(3 / 1)$ & $75^{\circ} \mathrm{C}$ & $15(0)$ \\
\hline 12 & $\mathrm{Pt}(+) / \mathrm{Pt}(-)$ & $\mathrm{Bu}_{4} \mathrm{NBr}$ (2.0 equiv) & $\mathrm{NaSO}_{2} \mathrm{CF}_{3}$ (2.0 equiv) & 1,2-Dimethoxyethane & $75^{\circ} \mathrm{C}$ & $46(7)$ \\
\hline 13 & $\mathrm{Pt}(+) / \mathrm{Pt}(-)$ & $\mathrm{Bu}_{4} \mathrm{NBr}$ (2.0 equiv) & $\mathrm{NaSO}_{2} \mathrm{CF}_{3}$ (2.0 equiv) & $\mathrm{ClCH}_{2} \mathrm{CH}_{2} \mathrm{Cl}$ & $75^{\circ} \mathrm{C}$ & Trace $(0)$ \\
\hline 14 & $\mathrm{C}(+) / \mathrm{Pt}(-)$ & $\mathrm{Bu}_{4} \mathrm{NBr}$ (2.0 equiv) & $\mathrm{NaSO}_{2} \mathrm{CF}_{3}$ (2.0 equiv) & $\mathrm{CH}_{3} \mathrm{CN}$ & $75^{\circ} \mathrm{C}$ & $71(0)$ \\
\hline 15 & $\mathrm{Pt}(+) / \mathrm{C}(-)$ & $\mathrm{Bu}_{4} \mathrm{NBr}$ (2.0 equiv) & $\mathrm{NaSO}_{2} \mathrm{CF}_{3}$ (2.0 equiv) & $\mathrm{CH}_{3} \mathrm{CN}$ & $75^{\circ} \mathrm{C}$ & $32(3)$ \\
\hline 16 & $\mathrm{C}(+) / \mathrm{C}(-)$ & $\mathrm{Bu}_{4} \mathrm{NBr}$ (2.0 equiv) & $\mathrm{NaSO}_{2} \mathrm{CF}_{3}$ (2.0 equiv) & $\mathrm{CH}_{3} \mathrm{CN}$ & $75^{\circ} \mathrm{C}$ & $33(7)$ \\
\hline $17^{\mathrm{C}}$ & $\mathrm{Pt}(+) / \mathrm{Pt}(-)$ & $\mathrm{Bu}_{4} \mathrm{NBr}$ (2.0 equiv) & $\mathrm{NaSO}_{2} \mathrm{CF}_{3}$ (2.0 equiv) & $\mathrm{CH}_{3} \mathrm{CN}$ & $75^{\circ} \mathrm{C}$ & $58(0)$ \\
\hline $18^{d}$ & $\mathrm{Pt}(+) / \mathrm{Pt}(-)$ & $\mathrm{Bu}_{4} \mathrm{NBr}$ (2.0 equiv) & $\mathrm{NaSO}_{2} \mathrm{CF}_{3}$ (2.0 equiv) & $\mathrm{CH}_{3} \mathrm{CN}$ & $75^{\circ} \mathrm{C}$ & $54(0)$ \\
\hline $19^{e}$ & $\mathrm{Pt}(+) / \mathrm{Pt}(-)$ & $\mathrm{Bu}_{4} \mathrm{NBr}$ (2.0 equiv) & $\mathrm{NaSO}_{2} \mathrm{CF}_{3}$ (2.0 equiv) & $\mathrm{CH}_{3} \mathrm{CN}$ & $75^{\circ} \mathrm{C}$ & Trace (0) \\
\hline $20^{f}$ & $\mathrm{Pt}(+) / \mathrm{Pt}(-)$ & $\mathrm{Bu}_{4} \mathrm{NBr}$ (2.0 equiv) & $\mathrm{NaSO}_{2} \mathrm{CF}_{3}$ (2.0 equiv) & $\mathrm{CH}_{3} \mathrm{CN}$ & $75^{\circ} \mathrm{C}$ & NR (97) \\
\hline
\end{tabular}

${ }^{a}$ Reaction conditions: $1 a(0.05 \mathrm{mmol})$, "Br" reagent, Additive, Solvent $(4.0 \mathrm{ml})$, Electrode, constant current $=2.0 \mathrm{~mA}, \mathrm{~T}, 4 \mathrm{~h}$, in an undivided cell, under an argon atmosphere.

${ }^{b}$ Yield of the isolated product, the yield of recovered starting material was represented in the parentheses.

$c=1.0 \mathrm{~mA}$

$d=3.0 \mathrm{~mA}$

eUnder an air atmosphere.

${ }^{f}$ No electricity.

2-bromoglycals, the development of a novel, practical, and environmentally friendly method for the synthesis of 2bromoglycals is still of high interest. The most common way to obtain 2-bromoglycals consists of two steps using $\mathrm{Br}_{2}$, which is toxic and unstable, as the brominating source
(Leibeling et al., 2010a). An alternative approach involves the one-step synthesis of 2-bromoglycals from glycals using $N$-bromosuccinimide and silver nitrate (Dharuman and Vankar, 2014). We herein report a one-step electrochemical bromination of glycals using commercially available, 
TABLE 2 | Substrate scope of glycals ${ }^{\mathrm{a}, \mathrm{b}, \mathrm{c}, \mathrm{d}, \mathrm{e}}$.

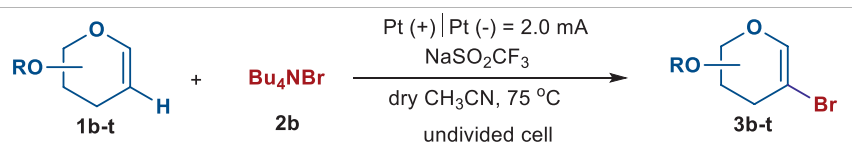<smiles>CC(=O)OCC1CCC(Br)=CO1</smiles>

3b, $73 \%^{\mathrm{c}}$<smiles>CC(C)(C)OC[C@H]1OC=C(Br)[C@@H]([18OH])[C@H]1[18OH]</smiles>

3f, $51 \%$

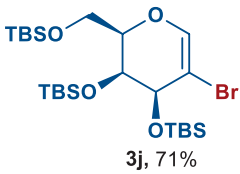<smiles>C[C@H]1OC=C(Br)[C@H]([18OH])[C@H]1[18OH]</smiles>

3n, $82 \%$<smiles>[18O]O[C@H]1C(Br)=COC[C@@H]1[18OH]</smiles><smiles>O=C(O)COC1CCC(Br)=CO1</smiles>

$3 c, 84 \%$<smiles>[CH]O[C@@H]1C(Br)=CO[C@H](COC)[C@@H]1OC</smiles><smiles></smiles><smiles>CCCCCO[C@@H]1[C@H](O[Na])C(Br)=CO[C@@H]1C</smiles><smiles>CCCCC[C@@H]1COC=C(Br)[C@@H]1O[Na]</smiles><smiles>O=C(O)C[C@H]1[C@H](O)C(Br)=CO[C@H]1COCc1ccccc1</smiles>

3d, $63 \%$<smiles>O=C(O)C[C@H]1OC=C(Br)[C@H](O)[C@H]1OCc1ccccc1</smiles>

3h, $56 \%(57 \%)^{d}$<smiles>O=C(O)COC1C(Br)=COC([18O])C1[18O]C(=O)c1ccccc1</smiles><smiles>CC(=O)O[C@H]1[C@@H](C)OC=C(Br)[C@@H]1OC(C)=O</smiles><smiles></smiles><smiles>CO[C@H]1COC=C(Br)[C@@H]1O[Na]</smiles>

3q, $74 \%$

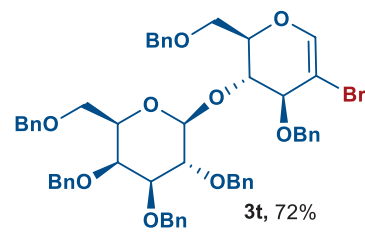

${ }^{a}$ Reaction conditions: glycals (0.05 mmol), $\mathrm{NaSO}_{2} \mathrm{CF}_{3}\left(0.10 \mathrm{mmol}, 2.0\right.$ equiv), $\mathrm{Bu} 4 \mathrm{NBr}\left(0.10 \mathrm{mmol}, 2.0\right.$ equiv), dry $\mathrm{CH}_{3} \mathrm{CN}(4.0 \mathrm{ml})$ in an undivided cell with Pt as the anode and cathode, constant current $=2.0 \mathrm{~mA}, 75^{\circ} \mathrm{C}$, under argon atmosphere, $4 \mathrm{~h}$.

${ }^{b}$ Yield of the isolated product.

${ }^{c}$ glycals $(0.10 \mathrm{mmol}), \mathrm{NaSO}_{2} \mathrm{CF}_{3}\left(0.20 \mathrm{mmol}, 2.0\right.$ equiv), $\mathrm{Bu} 4 \mathrm{NBr}\left(0.30 \mathrm{mmol}, 3.0\right.$ equiv), dry $\mathrm{CH}_{3} \mathrm{CN}(5.0 \mathrm{ml})$ in an undivided cell with Pt as the anode and cathode, constant current = $2.0 \mathrm{~mA}, 75^{\circ} \mathrm{C}$, under argon atmosphere, $6 \mathrm{~h}$.

${ }^{d}$ glycals $(0.60 \mathrm{mmol}), \mathrm{NaSO}_{2} \mathrm{CF}_{3}\left(1.20 \mathrm{mmol}, 2.0\right.$ equiv), $\mathrm{Bu} 4 \mathrm{NBr}\left(1.20 \mathrm{mmol}, 2.0\right.$ equiv), dry $\mathrm{CH}_{3} \mathrm{CN}(50.0 \mathrm{ml})$ in an undivided cell with Pt as the anode and cathode, constant current = $2.0 \mathrm{~mA}, 75^{\circ} \mathrm{C}$, under argon atmosphere, $30 \mathrm{~h}$.

${ }^{e}$ glycals $(0.05 \mathrm{mmol}), \mathrm{NaSO}_{2} \mathrm{CF}_{3}\left(0.10 \mathrm{mmol}, 2.0\right.$ equiv), $\mathrm{Bu} 4 \mathrm{NBr}\left(0.15 \mathrm{mmol}, 3.0\right.$ equiv), dry $\mathrm{CH}_{3} \mathrm{CN}(4.0 \mathrm{ml})$ in an undivided cell with Pt as the anode and cathode, constant current = $2.0 \mathrm{~mA}, 75^{\circ} \mathrm{C}$, under argon atmosphere, $6 \mathrm{~h}$.

stable, and safe $\mathrm{Bu}_{4} \mathrm{NBr}$ as the bromine source in an undivided cell under metal-catalyst-free and oxidant-free reaction conditions.

\section{RESULTS AND DISCUSSION}

Initially, we began our investigation with 6-O-benzyl-3,4dideoxy-glycal 1a as the model substrate for electrochemical bromination using $\mathrm{Pt}$ as the anode and cathode in an undivided cell. Unfortunately, no desired 2-bromo-3,4-dideoxy-glycal 3a was detected using $\mathrm{KBr}$ (Ye and Shreeve, 2004; Zhao and Lu, 2018) or $\mathrm{NaBr}$ (Alberto et al., 2014) as the "Br" reagent (Table 1, entries 1 and 2). To our delight, the product $3 \mathbf{a}$ could be obtained in $10 \%$ isolated yield when 1 a was treated with 1.5 equiv of $\mathrm{Bu}_{4} \mathrm{NBr}$ (Yoshimitsu et al., 2009; Kamon et al., 2012) in dry $\mathrm{CH}_{3} \mathrm{CN}$ at room temperature under a constant electric current of $2 \mathrm{~mA}$ (Table 1, entry 3). The yield was increased slightly when the reaction temperature was increased to $50^{\circ} \mathrm{C}$ (Table 1, entry 4). Further raising the temperature to $75^{\circ} \mathrm{C}$ was beneficial to this transformation, leading to the formation of $\mathbf{3 a}$ in $35 \%$ yield (Table $\mathbf{1}$, entry 5), and the yield could be increased to $40 \%$ when the amount of $\mathrm{Bu}_{4} \mathrm{NBr}$ was increased to 2.0 equiv (Table 1, entry 6). It was found that the addition of base, such as $\mathrm{K}_{2} \mathrm{CO}_{3}$ or $\mathrm{Na}_{2} \mathrm{CO}_{3}$, could further improve the reaction yield (Table 1, entries 7 and 8). Surprisingly, when the bromination reaction was conducted with $\mathrm{NaSO}_{2} \mathrm{CF}_{3}$ as the additive, the desired product $\mathbf{3 a}$ was isolated in $67 \%$ yield (Table 1, entry 9 ). Altering the amount of $\mathrm{NaSO}_{2} \mathrm{CF}_{3}$ to 2.0 equiv led to an increased yield of $82 \%$ 


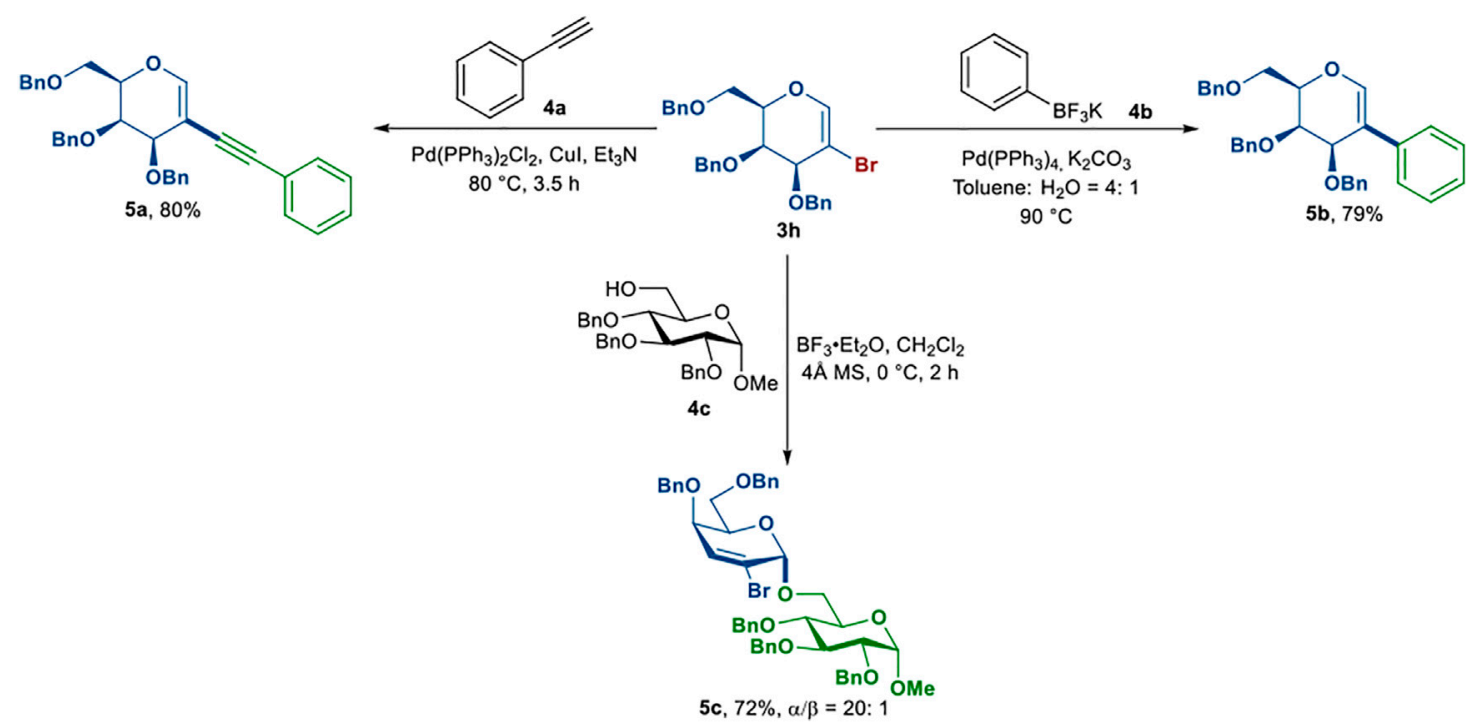

SCHEME 2 | Reaction of 2-bromogalactal (3h) with different substrates (4a-c).
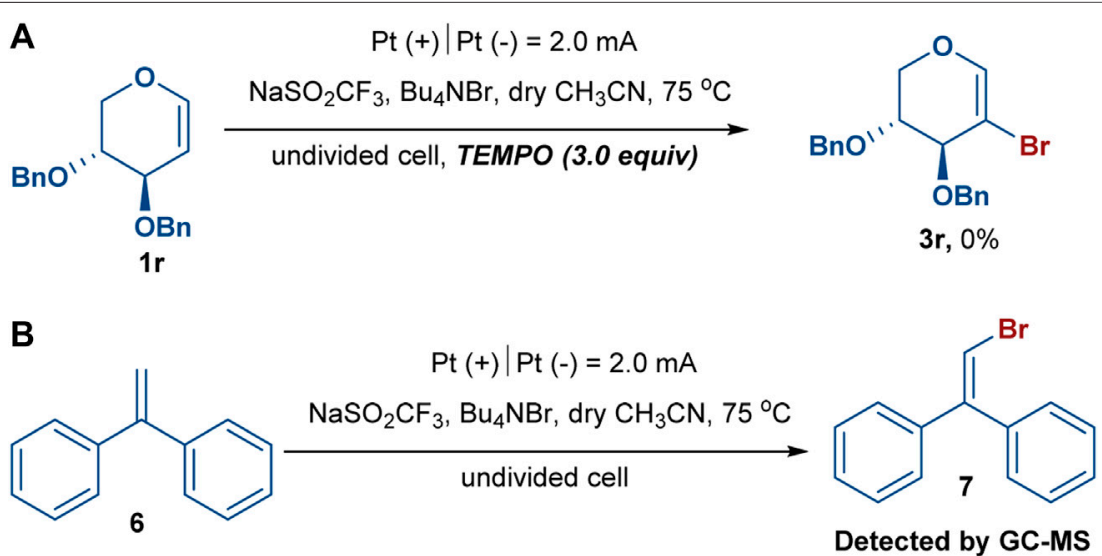

SCHEME 3 | In the radical trapping experiments, experiment (A) was performed with glycal (0.05 mmol) and TEMPO (0.15 mmol, 3.0 equiv) under standard reaction condition: NaSO2CF3 ( $0.10 \mathrm{mmol}, 2.0$ equiv), Bu4NBr ( $0.10 \mathrm{mmol}, 2.0$ equiv), dry $\mathrm{CH} 3 \mathrm{CN}$ ( $4.0 \mathrm{ml})$ in an undivided cell with Pt as the anode and cathode, constant current $=2.0 \mathrm{~mA}, 75 \mathrm{oC}$, under argon atmosphere, $4 \mathrm{~h}$. Besides, experiment (B) was performed with 1,1-diphenylethylene (0.15 mmol) under standard reaction condition as well.

(Table 1, entry 10). Comparatively, when other solvents such as $\mathrm{CH}_{3} \mathrm{CN} / \mathrm{H}_{2} \mathrm{O}$ (3:1), 1,2-dimethoxyethane, or $\mathrm{ClCH}_{2} \mathrm{CH}_{2} \mathrm{Cl}$, were used instead of dry $\mathrm{CH}_{3} \mathrm{CN}$, lower yields were achieved (Table 1, entries 11-13). Extensive screening experiments revealed that either changing electrode materials or modifying the reaction current were not effective for improving the yield of $\mathbf{3 a}$ (Table 1, entries 14-18). Moreover, the yield of $\mathbf{3 a}$ was decreased drastically when the electrochemical bromination reaction was performed in an air atmosphere (Table 1, entry 19). Finally, the control experiment confirmed that the role of electricity was essential, as the reaction could not proceed in the absence of an electric current (Table 1, entry 20).
With the optimal reaction conditions in hand, we then evaluated the substrate scope of the electrochemical bromination of various types of glycals with $\mathrm{Bu}_{4} \mathrm{NBr}$ (Table 2). First, 3,4-dideoxy-glycals with electronwithdrawing groups were examined. Substrates with an acetyl or benzoyl group provided the respective brominated products $\mathbf{3 b}$ and $\mathbf{3} \mathbf{c}$ in good yields. In addition, benzyl (Bn), p-methoxybenzyl (PMB), tert-butyldimethylsilyl (TBS), and methyl (Me) substituted glucals could also be converted into the corresponding products $\mathbf{3 d - g}$. Similarly, galactals bearing $\mathrm{Bn}, \mathrm{PMB}$, or TBS groups were found to be amenable to the electrochemical reaction, providing the desired products $\mathbf{3 h}-\mathbf{j}$ in $56-73 \%$ yields. And the scalability of this electrochemical 


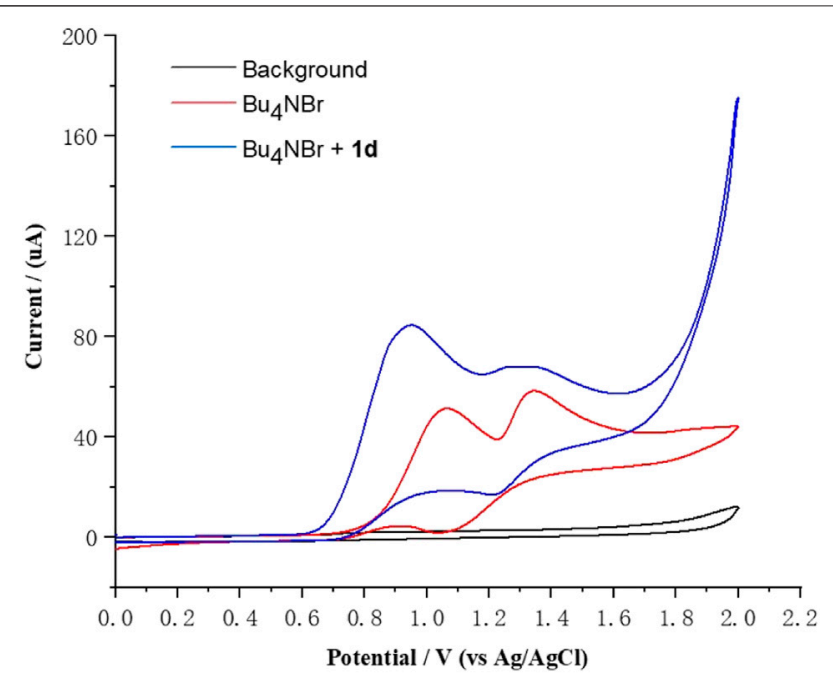

FIGURE 1 | Cyclic voltammetry measurements of $\mathrm{Bu}_{4} \mathrm{NBr}$ and 1d Conditions: glassy carbon disk electrode (diameter is $3.0 \mathrm{~mm}$, PTFE shroud) as the working electrode, platinum wire as the counter electrode, $\mathrm{Ag} / \mathrm{AgCl}$ electrode $\left(3.5 \mathrm{M} \mathrm{KCl}\right.$ solution) as the reference electrode, $\mathrm{Bu}_{4} \mathrm{NOTf}$ $(0.10 \mathrm{M}$ in $\mathrm{MeCN})$, under an argon atmosphere, cyclic voltammogram at $0.05 \mathrm{~V} \mathrm{~s}^{-1}$ with $\mathrm{Bu}_{4} \mathrm{NBr}(5 \mathrm{mM})$ or $\mathrm{Bu}_{4} \mathrm{NBr}(5 \mathrm{mM})$ and $\mathbf{1 d}(5 \mathrm{mM})$

bromination was further showed by an efficient conversion of compound $\mathbf{1 h}$ on a $250 \mathrm{mg}$ scale in $57 \%$ isolated yield. Peracetylated and perbenzoylated galactals could also undergo the electrochemical transformation to afford 2bromo-galactals $\mathbf{3 k - 1}$, albeit in slightly low yields. Notably, bromination of peracetylated L-rhamnal proceeded smoothly to deliver compound $\mathbf{3 m}$ in $89 \%$ yield. Under the same conditions, the L-rhamnal, L-arabinal, and D-xylal equipped with $\mathrm{Bn}$ or $\mathrm{PMB}$ groups were also able to furnish the corresponding brominated products $\mathbf{3 n}-\mathbf{s}$ in moderate to excellent yields. Furthermore, benzylated lactal 1t underwent this reaction to afford the desired product $3 \mathbf{t}$ in $72 \%$ yield.

To demonstrate the potential applicability of 2bromoglycals, the reaction of 2 -bromogalactal $3 \mathbf{h}$ with different substrates was carried out (Scheme 2). First, we explored the utility of 2 -bromogalactal $\mathbf{3 h}$ in the synthesis of 2C-substituted carbohydrates, which exist in many natural products (Yin and Linker, 2012; Dubbu et al., 2018; Darbem et al., 2020). Compound $\mathbf{3 h}$ reacted with phenylacetylene $4 \mathbf{a}$ in the presence of $\mathrm{Pd}\left(\mathrm{PPh}_{3}\right)_{2} \mathrm{Cl}_{2}, \mathrm{CuI}$ and $\mathrm{Et}_{3} \mathrm{~N}$ to afford the coupled product $\mathbf{5 a}$ in $80 \%$ yield (Koester and Werz, 2012). The reaction of $\mathbf{3 h}$ with potassium phenyltrifluoroborate $\mathbf{4 b}$ also proceeded smoothly to provide the corresponding product $5 \mathbf{b}$ in $79 \%$ yield (Molander and Fumagalli, 2006). Moreover, disaccharide 5c was successfully synthesized in the promotion of $\mathrm{BF}_{3} \cdot \mathrm{Et}_{2} \mathrm{O}$ in $72 \%$ yield with excellent $a$-selectivity via the Ferrier rearrangement reaction (Dharuman et al., 2013; Wang et al., 2019).

To gain insight into the mechanism of this electrochemical bromination, radical trapping experiments were performed. As expected, the reaction was completely shut down when 3.0 equiv of the radical scavenger 2,2,6,6-tetramethylpiperidine-1oxyl (TEMPO) was added under the standard reaction conditions, indicating that radical chemistry was likely involved in the reaction (Scheme 3A) (Makai et al., 2020; Wang et al., 2019). Furthermore, another experiment using 1,1-diphenylethylene (6) was also conducted under the standard reaction conditions, and (2-bromoethene-1,1-diyl) dibenzene (7) was successfully detected in the GC-MS, confirming the participation of the bromine radical in the reaction system (Scheme 3B) (Chen et al., 2020; Kale et al., 2021). We observed that the reaction mixture gradually turned brown during the reaction process, indicating that $\mathrm{Br}_{2}$ might be generated. The 2 -bromoglycal $3 \mathbf{h}$ was resubmitted to the standard reaction conditions for $20 \mathrm{~h}$ with the recovery of $\mathbf{3 h}$ in a $78 \%$ yield. In addition, cyclic voltammetry experiments were carried out to investigate the redox behavior of the reaction. The cyclic voltammetry measurements of $\mathrm{Bu}_{4} \mathrm{NBr}$ indicated two obvious oxidative peaks at 1.07 and $1.37 \mathrm{~V}$ (vs. $\mathrm{Ag} / \mathrm{AgCl}$ ) (Figure 1, red curve), which likely corresponded to $\mathrm{Br}_{3}{ }^{-} / \mathrm{Br}^{-}$and $\mathrm{Br}_{3}{ }^{-} / \mathrm{Br}_{2}$ redox couples, respectively (Damljanovic et al., 2011; Bennett et al., 2016; Kang et al., 2016). The first oxidative peak was associated with the oxidation of $\mathrm{Br}^{-}$to the bromine radical. The bromine

Anode
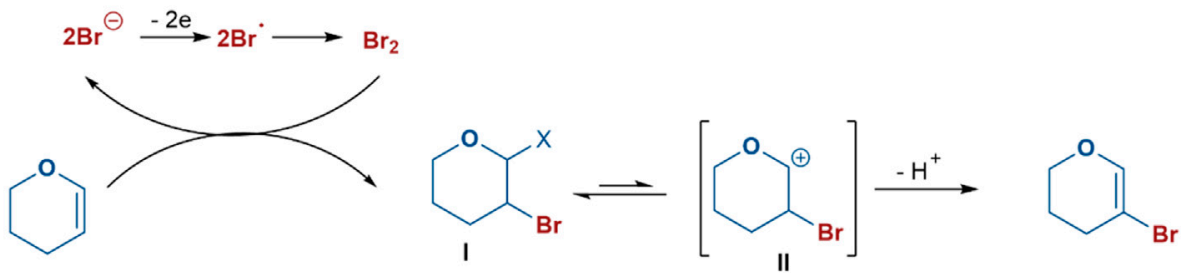

$\mathrm{X}=\mathrm{CF}_{3} \mathrm{SO}_{2}, \mathrm{Br}$

Cathode $2 \mathrm{H}^{\oplus} \stackrel{+2 \mathrm{e}}{\longrightarrow} \mathrm{H}_{2}$

SCHEME 4 | Plausible reaction mechanism for the electrochemical bromination of glycals. 
radical then integrated into $\mathrm{Br}_{2}$, which could combine with $\mathrm{Br}^{-}$to form $\mathrm{Br}_{3}{ }^{-}$. The second oxidative peak was attributed to the oxidation of $\mathrm{Br}_{3}{ }^{-}$to $\mathrm{Br}_{2}$. An increase in the oxidative peak current was observed when $\mathrm{Bu}_{4} \mathrm{NBr}$ and $\mathbf{1 d}$ were combined, which was attributed to a catalytic current, resulting from the chemical reaction of the electrochemically-generated $\mathrm{Br}_{2}$ and glucal 1d (Figure 1, blue curve).

\section{Mechanism}

Based on the above results and previous reports (Yuan et al., 2019; Gou et al., 2021; Wu et al., 2021), a plausible reaction mechanism for the electrochemical bromination of glycals was depicted in Scheme 4. A bromine anion was oxidized to the bromine radical on the anode and subsequently molecular $\mathrm{Br}_{2}$. This was then attacked by glycal to yield the intermediate I. Finally, the brominated product was obtained by the deprotonation of II, which would be stabilized by acetonitrile. $\mathrm{NaSO}_{2} \mathrm{CF}_{3}$ might be used as the electrolyte to increase the conductivity of the reaction solution and a proton scavenger to generate strong acid for cathode reduction; besides, it may be an anion to stabilize the glycosyl cation. At the same time, $\mathrm{H}^{+}$was reduced to produce hydrogen on the cathode.

\section{CONCLUSION}

In summary, we performed the one-step electrochemical bromination of various glycals with electron-withdrawing and electron-donating protective groups using commercially available, nontoxic $\mathrm{Bu}_{4} \mathrm{NBr}$ as the brominating source under metal-catalyst-free and oxidant-free reaction conditions. The synthetic applicability of 2-bromoglycals has been demonstrated by providing the corresponding $2 \mathrm{C}$-substituted carbohydrates and disaccharides via palladium-catalyzed cross-coupling reactions and the Ferrier rearrangement reaction. The readily available substrates and ease of handling make this methodology a practical tool to

\section{REFERENCES}

Alberto, E. E., Muller, L. M., and Detty, M. R. (2014). Rate Accelerations of Bromination Reactions with $\mathrm{NaBr}$ and $\mathrm{H}_{2} \mathrm{O}_{2}$ via the Addition of Catalytic Quantities of Diaryl Ditellurides. Organometallics 33, 5571-5581. doi:10.1021/ om500883f

Bennett, B., Chang, J., and Bard, A. J. (2016). Mechanism of the $\mathrm{Br}-/ \mathrm{Br}_{2}$ Redox Reaction on Platinum and Glassy Carbon Electrodes in Nitrobenzene by Cyclic Voltammetry. Electrochimica Acta 219, 1-9. doi:10.1016/j.electacta.2016.09.129

Chen, D., Li, J., Cui, P., Shan, Y., Zhao, Y., and Qiu, G. (2020). Tandem Oxidative Radical Halogenated Addition of Alkynyl Imines: Regioselective Synthesis of 3-Haloquinolines. Eur. J. Org. Chem. 2020, 169-175. doi:10.1002/ ejoc. 201901395

Damljanović, I., Stevanović, D., Vukićević, M., and Vukićević, R. D. (2011). Electrochemical Bromochlorination of Peracetylated Glycals. Carbohydr. Res. 346, 2683-2687. doi:10.1016/j.carres.2011.09.016

Darbem, M. P., Esteves, H. A., Oliveira, I. M., and Stefani, H. A. (2020). $\alpha, \beta$-Unsaturated 2-Ketoglycosides via Pd-Catalyzed Carbonylative Heck Reaction of 2-Iodoglycals. Eur. J. Org. Chem. 2020, 5220-5226. doi:10.1002/ ejoc. 202000846

Dharuman, S., Gupta, P., Kancharla, P. K., and Vankar, Y. D. (2013). Synthesis of 2-Nitroglycals from Glycals Using the Tetrabutylammonium access diversified brominating synthons for the preparation of biologically relevant carbohydrates.

\section{DATA AVAILABILITY STATEMENT}

The original contributions presented in the study are included in the article/Supplementary Material, further inquiries can be directed to the corresponding authors.

\section{AUTHOR CONTRIBUTIONS}

Z-XL and ML contributed equally to this work. Z-XL, ML, and TL performed the experiments. Z-XL and ML carried out the mechanistic studies. Z-XL, ML, D-CX, and X-SY analyzed and discussed the research results. D-CX and $\mathrm{X}-\mathrm{SY}$ designed the experiments. Z-XL, ML, and D-CX wrote the manuscript.

\section{FUNDING}

This research was funded by grants from the National Natural Science Foundation of China (Grant Nos. 21772006, 91853122), the Beijing Outstanding Young Scientist Program (BJJWZYJH01201910001001), the open fund of State Key Laboratory of Pharmaceutical Biotechnology, Nanjing University, China (Grant no. KF-GN-202106), and the Fundamental Research Funds for the Central Universities.

\section{SUPPLEMENTARY MATERIAL}

The Supplementary Material for this article can be found online at: https://www.frontiersin.org/articles/10.3389/fchem.2021.796690/ full\#supplementary-material

Nitrate-Trifluoroacetic Anhydride-Triethylamine Reagent System and BaseCatalyzed Ferrier Rearrangement of Acetylated 2-Nitroglycals. J. Org. Chem. 78, 8442-8450. doi:10.1021/jo401165y

Dharuman, S., and Vankar, Y. D. (2014). $\mathrm{N}$-Halosuccinimide/ $\mathrm{AgNO}_{3}$-Efficient Reagent Systems for One-step Synthesis of 2-Haloglycals from Glycals: Application in the Synthesis of $2 C$-Branched Sugars via Heck Coupling Reactions. Org. Lett. 16, 1172-1175. doi:10.1021/ol500039s

Dubbu, S., Verma, A. K., Parasuraman, K., and Vankar, Y. D. (2018). Stereoselective Synthesis of 1,2-Annulated-C-Aryl Glycosides from Carbohydrate-Derived Terminally Unsubstituted Dienes and Arynes: Application towards Synthesis of Sugar-Fused- or Branched- Naphthalenes, and C-Aryl Glycosides. Carbohydr. Res. 465, 29-34. doi:10.1016/ j.carres.2018.06.001

Francke, R., and Little, R. D. (2014). Redox Catalysis in Organic Electrosynthesis: Basic Principles and Recent Developments. Chem. Soc. Rev. 43, 2492-2521. doi:10.1039/c3cs60464k

Gou, X.-Y., Li, Y., Luan, Y.-Y., Shi, W.-Y., Wang, C.-T., An, Y., et al. (2021). Ruthenium-Catalyzed Radical Cyclization/meta-Selective C-H Alkylation of Arenes via $\sigma$-Activation Strategy. ACS Catal. 11, 4263-4270. doi:10.1021/ acscatal.1c00359

Horn, E. J., Rosen, B. R., Chen, Y., Tang, J., Chen, K., Eastgate, M. D., et al. (2016). Scalable and Sustainable Electrochemical Allylic C-H Oxidation. Nature 533, 77-81. doi:10.1038/nature17431 
Kamon, T., Shigeoka, D., Tanaka, T., and Yoshimitsu, T. (2012). Intramolecular Iron(II)-catalyzed Aminobromination of Allyl N-Tosyloxycarbamates. Org. Biomol. Chem. 10, 2363-2365. doi:10.1039/c2ob07190h

Kang, L.-S., Luo, M.-H., Lam, C. M., Hu, L.-M., Little, R. D., and Zeng, C.-C. (2016). Electrochemical C-H Functionalization and Subsequent C-S and C-N Bond Formation: Paired Electrosynthesis of 3-Amino-2-Thiocyanato$\alpha, \beta$-Unsaturated Carbonyl Derivatives Mediated by Bromide Ions. Green. Chem. 18, 3767-3774. doi:10.1039/c6gc00666c

Kiessling, L. L., and Kraft, M. B. (2013). A Path to Complex Carbohydrates. Science 341, 357-358. doi:10.1126/science. 1241788

Koester, D. C., and Werz, D. B. (2012). Sonogashira-Hagihara Reactions of Halogenated Glycals. Beilstein J. Org. Chem. 8, 675-682. doi:10.3762/ bjoc. 8.75

Leibeling, M., Koester, D. C., Pawliczek, M., Kratzert, D., Dittrich, B., and Werz, D. B. (2010a). Hybrids of Sugars and Aromatics: A Pd-Catalyzed Modular Approach to Chromans and Isochromans. Bioorg. Med. Chem. 18, 3656-3667. doi:10.1016/j.bmc.2010.03.004

Leibeling, M., Koester, D. C., Pawliczek, M., Schild, S. C., and Werz, D. B. (2010b). Domino Access to Highly Substituted Chromans and Isochromans from Carbohydrates. Nat. Chem. Biol. 6, 199-201. doi: $10.1038 /$ nchembio. 302

Leibeling, M., and Werz, D. B. (2012). Winding up Alkynes: A Pd-Catalyzed Tandem-Domino Reaction to Chiral Biphenyls. Chem. Eur. J. 18, 6138-6141. doi:10.1002/chem.201200175

Li, B.-H., and Ye, X.-S. (2020). Recent Advances in Glycan Synthesis. Curr. Opin. Chem. Biol. 58, 20-27. doi:10.1016/j.cbpa.2020.04.009

Liang, S., and Zeng, C.-C. (2020). Organic Electrochemistry: Anodic Construction of Heterocyclic Structures. Curr. Opin. Electrochemistry 24, 31-43. doi:10.1016/ j.coelec.2020.06.005

Liu, M., Liu, K. M., Xiong, D. C., Zhang, H., Li, T., Li, B., et al. (2020). Stereoselective Electro-2-deoxyglycosylation from Glycals. Angew. Chem. Int. Ed. 59, 15204-15208. doi:10.1002/anie.202006115

Liu, M., Luo, Z.-X., Li, T., Xiong, D.-C., and Ye, X.-S. (2021). Electrochemical Trifluoromethylation of Glycals. J. Org. Chem. 86, 16187-16194. doi:10.1021/ acs.joc.1c01318

Makai, S., Falk, E., and Morandi, B. (2020). Direct Synthesis of Unprotected 2-Azidoamines from Alkenes via an Iron-Catalyzed Difunctionalization Reaction. J. Am. Chem. Soc. 142, 21548-21555. doi:10.1021/jacs.0c11025

Manmode, S., Matsumoto, K., Nokami, T., and Itoh, T. (2018). Electrochemical Methods as Enabling Tools for Glycosylation. Asian J. Org. Chem. 7, 1719-1729. doi:10.1002/ajoc.201800302

Martin, A., Arda, A., Désiré, J., Martin-Mingot, A., Probst, N., Sinaÿ, P., et al. (2015). Catching Elusive Glycosyl Cations in a Condensed Phase with $\mathrm{HF} / \mathrm{SbF}_{5}$ Superacid. Nat. Chem 8, 186-191. doi:10.1038/ nchem. 2399

Meyer, T. H., Choi, I., Tian, C., and Ackermann, L. (2020). Powering the Future: How Can Electrochemistry Make a Difference in Organic Synthesis? Chem 6, 2484-2496. doi:10.1016/j.chempr.2020.08.025

Molander, G. A., and Fumagalli, T. (2006). Palladium(0)-Catalyzed Suzuki-Miyaura Cross-Coupling Reactions of Potassium Aryl- and Heteroaryltrifluoroborates with Alkenyl Bromides. J. Org. Chem. 71, 5743-5747. doi:10.1021/jo0608366

Muthana, S., Cao, H., and Chen, X. (2009). Recent Progress in Chemical and Chemoenzymatic Synthesis of Carbohydrates. Curr. Opin. Chem. Biol. 13, 573-581. doi:10.1016/j.cbpa.2009.09.013

Nokami, T., Isoda, Y., Sasaki, N., Takaiso, A., Hayase, S., Itoh, T., et al. (2015). Automated Electrochemical Assembly of the Protected Potential TMGChitotriomycin Precursor Based on Rational Optimization of the
Carbohydrate Building Block. Org. Lett. 17, 1525-1528. doi:10.1021/ acs.orglett.5b00406

Panza, M., Pistorio, S. G., Stine, K. J., and Demchenko, A. V. (2018). Automated Chemical Oligosaccharide Synthesis: Novel Approach to Traditional Challenges. Chem. Rev. 118, 8105-8150. doi:10.1021/acs.chemrev.8b00051

Prabhakar Kale, A., Nikolaienko, P., Smirnova, K., and Rueping, M. (2021). Intramolecular Electrochemical Oxybromination of Olefins for the Synthesis of Isoxazolines in Batch and Continuous Flow. Eur. J. Org. Chem. 2021, 3496-3500. doi:10.1002/ejoc.202100640

Wang, J., Deng, C., Zhang, Q., and Chai, Y. (2019). Tuning the Chemoselectivity of Silyl Protected Rhamnals by Temperature and Brønsted Acidity: Kinetically Controlled 1,2-Addition vs Thermodynamically Controlled Ferrier Rearrangement. Org. Lett. 21, 1103-1107. doi:10.1021/acs.orglett.9b00009

Wang, Y., Carder, H. M., and Wendlandt, A. E. (2020). Synthesis of Rare Sugar Isomers through Site-Selective Epimerization. Nature 578, 403-408. doi:10.1038/s41586020-1937-1

Wu, Y., Xu, S., Wang, H., Shao, D., Qi, Q., Lu, Y., et al. (2021). Directing Group Enables Electrochemical Selectively Meta-Bromination of Pyridines under Mild Conditions. J. Org. Chem. 86, 16144-16150. doi:10.1021/acs.joc.1c00923

Ye, C., and Shreeve, J. n. M. (2004). Structure-Dependent Oxidative Bromination of Unsaturated C-C Bonds Mediated by Selectfluor. J. Org. Chem. 69, 8561-8563. doi:10.1021/jo048383x

Yin, J., and Linker, T. (2012). Recent Advances in the Stereoselective Synthesis of Carbohydrate 2-C-Analogs. Org. Biomol. Chem. 10, 2351-2362. doi:10.1039/ c2ob06529k

Yoshimitsu, T., Ino, T., Futamura, N., Kamon, T., and Tanaka, T. (2009). Total Synthesis of the $\beta$-Catenin Inhibitor, (-)-Agelastatin A: A Second-Generation Approach Based on Radical Aminobromination. Org. Lett. 11, 3402-3405. doi:10.1021/ol9012684

Yuan, Y., Yang, J., and Lei, A. (2021). Recent Advances in Electrochemical Oxidative Cross-Coupling with Hydrogen Evolution Involving Radicals. Chem. Soc. Rev. 50, 10058-10086. doi:10.1039/d1cs00150g

Yuan, Y., Yao, A., Zheng, Y., Gao, M., Zhou, Z., Qiao, J., et al. (2019). Electrochemical Oxidative Clean Halogenation Using $\mathrm{HX} / \mathrm{NaX}$ with Hydrogen Evolution. Iscience 12, 293-303. doi:10.1016/j.isci.2019.01.017

Zhang, H. Y., Liu, M., Wu, X., Liu, M., Xiong, D. C., and Ye, X. S. (2020). Photo-/ Electro-Driven Carbohydrate-Based Reactions. Prog. Chem. 32, 1804-1823. doi: $10.7536 / p c 200608$

Zhao, M., and Lu, W. (2018). Catalytic Bromination of Alkyl $s p^{3} \mathrm{C}-\mathrm{H}$ Bonds with KBr/Air under Visible Light. Org. Lett. 20, 5264-5267. doi:10.1021/ acs.orglett. 8 b02208

Conflict of Interest: The authors declare that the research was conducted in the absence of any commercial or financial relationships that could be construed as a potential conflict of interest.

Publisher's Note: All claims expressed in this article are solely those of the authors and do not necessarily represent those of their affiliated organizations, or those of the publisher, the editors and the reviewers. Any product that may be evaluated in this article, or claim that may be made by its manufacturer, is not guaranteed or endorsed by the publisher.

Copyright (c) $2021 \mathrm{Luo}, \mathrm{Liu}, \mathrm{Li}$, Xiong and Ye. This is an open-access article distributed under the terms of the Creative Commons Attribution License (CC BY). The use, distribution or reproduction in other forums is permitted, provided the original author(s) and the copyright owner(s) are credited and that the original publication in this journal is cited, in accordance with accepted academic practice. No use, distribution or reproduction is permitted which does not comply with these terms. 